\title{
МЕЖДУНАРОДНАЯ ЗАЩИТА ПРАВ ЖЕНЩИН
}

\author{
М.В. Л ом а кин а *
}

Во всех мехдународных правозащитных документах подчеркивается, что права человека универсальны, в том смысле что они применимы к каждому человеку. Статья 2 Международного пакта о грахданских и политических правах требует, чтобы кахдое государство кувахало и обеспечивало всем лицам на своей территории предоставляемые им права без каких-либо различий на основе расовой принадлежности, цвета кожи, пола, языка, религиозных, политических и иных взглядов, национального или социального происхождения, имущественного или иного статуca».

Очевидно, что нарушение прав хеншин присутствует во всех ситуация х нарушения прав человека, однахо необходимо обращать внимание на специфически гендерные проблемы и рассматривать права женщин как осоую группу.

Хотя ядро правозащитных инструментов ООН (Хартия ООН, Всемирная декларация прав человека, Пакт о грахданских и политических правах и Пакт $\infty$ экономических, социальных и культурных- правах) отводит женщинам те же права, что и мужчинам, исторически сложилось так, что мехдународные дебаты по правам человека всегда избегали обсуждения женских прав как прав человека. Конвенция по ликвидации всех форм дискриминации женщин представляет собой шаг вперед в обсуждении женских прав, но она не включает женские права в основной контекст правозащитных дебатов ${ }^{1}$.

Исходя из этого, представляется необходимым рассматривать права женшин как специфическую группу прав. При этом дискуссии по правам женщин должны вестись не изолированно, а в общем контексте защиты прав человека, чтобы интересы женщин постоянно обеспечивались в той позиции, которую занимает правозашитное движение по различным вопросам.

Уже на ранних стадиях функционирования ООН права женщин широко обсуждались в органах, занимающихся защитой прав человека, а в 1946 году была создана Комиссия по положению женщин, наделенная полномочиями проводить исследования и подготавливать рекомендации по правам человека, имеющим особо важное значение для женщин. Первоочередной задачей этой комиссии было определение в мировом масштабе условий и ситуаций, в ко-

* Аспирантка хафедры международного права МГИМО(У) МИД РФ. 
торых женщины подвергаются наиболее жестокой дискриминации. Следующие сферы находились в фокусе работы комиссии:

- политические права и возможности пользования ими;

- юридические права женщин как в качестве индивидуумов, так и в качестве членов семьи;

- доступ девушек и женщин к образованию и различным формам обучения, в том числе профессионального;

- трудовая жизнь.

На протяжении последних 50 лет ООН, ЮНЕСКО и МОТ разработали и приняли различные рекомендации и конвенции, касающиеся всех вышеперечисленных областей ${ }^{2}$.

В 1979 году была принята наиболее значительная конвенция ООН в рассматриваемой области: Конвенция о ликвидации всех форм дискриминации в отношении женщин. Этот документ явился итогом более чем 30-летней работы в рамках $О 0 \mathrm{H}$, направленной на включение принципа гендерного равенства в международное право.

Для целей Конвенции потребовалось дать определение «дискриминации женщин». В статье 1 говорится: «...термин "дискриминация женщин" означает любое разграничение, изоляцию или запрет, основанные на половых различиях, хоторые имеют свонм результатом или целью ограничить или аннулировать признание, соблюдение или реализацию человеческих прав и фундаментальных свобод женшин в политической, экономической, социальной, культурной, гражданской или любой другой сфере».

В соответствии с Конвенцией в целя х контроля над соблюдением ее положений также был учрежден Комитет по ликвидации дискриминации женщин.

Помимо указанной Конвенции, большой вклад в фбеспечение того, чтобы права женщин рассматривались наряду с другими правами человека, внесли Конференции ООН по правам женщин. Первая Всемирная конференция по положению женщин состоялась в Мехико в 1975 году в рамках Международного года женщины. На ней был принят первый Всемирный план действий и провозглашено первое Десятилетие женщины: равенство, развитие, мир. Вторая Всемирная конференция, созванная в Копенгагене в 1980 году, рассматривала дополнительные подтемы: «Образование, занятость и здравоохранение». Третья Конференция, проходившая в Найроби в 1985 году, включила эти темы в Найробийские перспективные стратегии в области улучшения положения женщин в период до 2000 года. В повестку для четвертой Всемирной конференции, состоявшейся в Пекине в 1995 году, вошел весь спектр проблем, касающихся женшин. На всех конференциях ООН по положению женщин было признано, что права женщин являются 
неотьемлемой частью прав человека, что при защите этих прав неприемлем «культурный релятивизм» и, что все права женшин носят фундаментальный и универсальный характер.

Вообше за 20 лет, прошедших после первой конференции в Мехико в 1975 году, кампания борьбы за равноправие мужчин и женщин претерпела значительные изменения и достигла несомненных успехов. Права женщин получают все более широкое признание, а в центре внимания активистов женского движения оказываются не только вопросы экономического развития и равенства, но и более непосредственные угрозы в отношении женщины как личности. Например, в Конвенции 1979 года даже не упоминалось о насилии в отношении женщин, поскольку не было общего признания того, что эта проблема относится К области прав человека. Однако теперь наснлие в отношении женщин привлекает к себе внимание как проблема, требуюшая срочного решения. В 1993 году Генеральная Ассамблея ООН приняла Декларацию о ликвидации насилия в отношении женщин - первый универсальный правовой документ, вводяший положение о недопустимости жестокого обращения в международно-правовые нормы по правам человека.

Помимо этого правительства приняли важные законы, соответствующие обеспечению равных возможностей, равного обращения с женщинами и равных прав для женщин. Женщины в настоящее время выступают в беспрецедентных масштабах на рынке труда, стремясь играть более значительную роль на всех уровнях общественной жизни и получая доступ $\mathrm{x}$ надлежашему медицинскому обслуживанию, образованию и гражданскому правосудию, что имеет решаюшее значение. Однако миллионы женщин по-прежнему подвергаются дискриминации в социальной, экономической, политической областях, а также в области культуры. По данным «Хроники ООН», в 1973 году во всем мире насчитываліось всего шесть женшин, возглавлявших правительства. В настоящее время из 184 послов, аккредитованных при ООН, только 6 - женщины. Заработная плата женщин в мире в среднем на $30-40 \%$ ниже заработной платы мужчин, выполняющих ту же работу ${ }^{3}$.

Наряду с тем, что международные документы закрепили многочисленные достижения в работе, направленной на признание равных прав женшин, эти документы обладают и сушественными недостатками.

Так, например, в Венской декларации, принятой на Конференции ООН по правам человека в 1993 году, говорится, что «все права человека универсальны, неделимы, взаимозависимы и взаимосвяза-

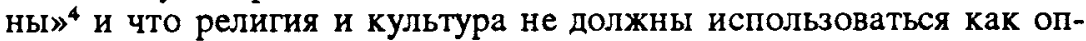
равдание нарушения прав женщин. Но тот факт, что Декларация уделяет особое внимание «национальным и региональным особен- 
ностям, историческим, культурным и религиозным корням», оставляет слишком много мест для толкований, противоречащих интересам женщин.

При ратификации Конвенции о ликвидации всех форм дискриминации в отношении женщин в 1979 году значительным числом государств были внесены обширные оговорки. Посредством таких оговорок государства освобождают себя от обязательств устранить дискриминацию женшин го религиозным и культурным основаниям, что является нарушением универсального характера прав человека ${ }^{5}$.

Международные правозащитные механизмы также далеки от совершенства. Работе контрольных органов ООН в области прав человека, а именно Комиссии по правам человека, Комиссии по положению женщин и различным специализированным учреждениям, свойственны дублирование, перенос рассмотрения многочисленных вопросов повестки дня на следующие сессии из года в год. Кроме того, сами государства не предоставляют свои доклады в срок, искажают статистику. Не ведется контроль за выполнением государствами решений, рекомендаций и замечаний, принимаемых органами ООН; многие из таких решений игнорируются государствами ${ }^{6}$. Недостаток конвенционных правозащитных механизмов, каковым является Комитет по ликвидации дискриминации женщин, заключается в том, что они недоступны для граждан тех стран, которые не участвуют в Конвенции.

На венской Конференции по правам человека было сформулировано несколько рекомендаций по улучшению процедур контроля и мониторинга, в частности: установление факультативного протокола в рамках Конвенции по правам женщин, назначение Особого докладчика при Комиссии ООН по правам человека, обучение сотрудников ООН умению распознавать нарушения прав женшин и т.д. Однако эти рекомендации пока не являются обязательными, и для вступления их в силу требуются действия других органов.

Наряду с универсальными, сушествуют и региональные механизмы в области прав человека. Механизм, предусмотренный Европейской конвенцией по правам человека, является наиболее развитым и применимым к большинству европейских государств, подписавших Конвенцию.

Европейская конвенция о правах человека содержит перечень традиционных гражданских и политических прав, однако включает также и жизнь в семье (ст. 8 и 12). Статья 14 Конвенции подтверждает, что «реализация прав и свобод, провозглашенных в данной Конвенции, будет обеспечена без дискриминации на каких бы то ни было основаниях, таких как пол, раса, цвет кожи, язык, религия, политические или иные взгляды, национальное или социаль- 
ное пронсхождение, приналлежность к национальным меньшинствам, имущественный статус, статус по рождению или какой-либо иной». Однако в этих документах не предусмотрено отдельное положение, которое гарантировало бы права женщин. В 1988 году Комитет министров принял Декларацию о равенстве мужчин и женщин, в которой говорится, что «равенство женщин и мужчин является принципом прав человека, провозглашенным как фундаментальное право во многих мехдународных документах", и что «дискриминация по признаку пола в политической, экономической, социальной, образовательной, культурной и любой другой сфере составляет препятствие $\mathrm{K}$ признанию, реализации и использованию прав и фундаментальных свобод человека».

Однако европейский механизм также не лишен недостатков, снижающих его эффективность. Так, прежде чем заявление будет принято комиссией, должны быть исчерпаны все средства решения проблемы на национальном уровне. Очевидно, что при выполнении данного требования могут возникнуть проблемы, связанные с труднодоступностью правосудия в правовой системе того или иного государства. $\mathrm{K}$ тому же, Комиссия не всегда предоставляет правовую помощь в использованин местных средств: в некоторых случаях Комиссия может счесть целесообразной и предоставить такую правовуго помощь, но это далеко не гарантировано. Кроме того, заявление не будет рассмотрено, если оно уже подано на рассмотрение по другой процедуре мехдународного расследования или урегулирования и не содержит новой информации. Даже когда жалоба принимается, необходимо иметь в виду, что в настояшее время средний срок с момента подачи заявления до вынесения решения судом составляет пять лет. В 1992 году было начато более 1800 новых дел ${ }^{7}$ Европейская конвенция по правам человека охватывает в первую очередь гражданские и политические права, но не экономические, социальные и культурные, которые часто бывают более актуальными для женшин.

Вообще, эффективность международного правозащитного законодательства и его механизмов зависит еще и от того, насколько они доступны, что относится как к универсальным, так и к региональным системам. Существенную проблему в этой области представляет недостаточная информированность граждан о содержании механизмов и процедурах их работы. Кроме того, мер воздействия, находящихся в распоряжении международных правозашитных механизмов, явно недостаточно. Так, нередко нарушения прав женщин совершаются не государством или его представителями, а частными лицами. Это верно в первую очередь в отношении насилия против женщин, дискриминации женщин в сфере трудоустройства и приобретения прав на землю. Некоторые государства отстаивают 
ту точку зрения, что такие нарушения не касаются международного правозащитного законодательства, так как они не заложены в законах государства, а относятся $\mathrm{K}$ сфере частной жизни. Этот аргумент не обоснован: статья 2 Международного пакта о гражданских и политических правах обязывает государства «обеспечить всем лицам, находящимся на их территории и подпадающим под их юрисдикцию, все права, предусмотренные в данном Пакте...», но тем не менее является очевидным, что действенность мехдународных правозащитных механизмов зависит от политической готовности государств обсуждать конкретные случаи и ситуации с другими странами-участницами.

Обязанностью государств - участников международных соглашений является создание и развитие национальных механизмов правовой зашиты. Согласно принципу мехдународной ответственности государств, государство несет юридическую ответственность за нарушение взятых на себя международных обязательств. Международные правовые положения о государственной ответственности за нарушения прав человека в последнее время получили значительное развитие. Статья 2 Конвенции о ликвидации всех форм дискриминации женщин требует от государств-участников обеспечить соблюдение Конвенции государственными органами и «принять все необходимые меры» для «ликвидации дискриминации во всех ее формах со стороны любого частного лица, организации или предприятия», а также по «изменению или отмене сушествуюших законов, постановлений, обычаев и практики, которые содержат дискриминацию женщин».

Поскольку многие положения договоров в области прав человека не являются самоисполнимыми, для реализации их норм необходимо принятие захонодательных и иных мер. Нередко простого закрепления определенного комплекса прав во внутреннем законодательстве недостаточно. Так, например, Российская Конституция ввела в национальную систему весь комплекс закрепленных международным правом основных прав и свобод человека. Часть 3 статьи 19 Конституции определяет, что мужчина и женщина имеют равные права и свободы. Статья 38 направлена на защиту материнства и детства. Гарантии равенства прав мужчин и женщин, а также привилегии, предоставляемые женщинам, закреплены также в трудовом и семейном законодательстве. Но означает ли это, что принцип равенства прав реализуется в России в полной мере?

Последствия экономических и политических изменений в России особенно отразились на женщинах: они, в частности, повсеместно сталкиваются с дискриминацией при приеме на работу и увольнении с работы. Российские правоохранительные органы не беспечивают равенство женщин перед законом, так же как не 
обеспечивают возбуждение дел по фактам насилия над женщинами, проведение расследования и передачу дела в суд. В марте 1994 года в рамках проекта по правам женщин, осуществляемого правозащитной организацией Хьюман Райтс Вотч, в Россию была направлена исследовательская группа с целью изучения вопроса о степени участия государства в дискриминации женщин ${ }^{8}$. Предположение о том, что установление демократии и переход к рыночной экономике создадут лучшие условия для зашиты прав человека в России, подтвердилось в том, что касается права на свободу ассоциаций и свободу слова, но права женщин, и без того далеко не так хорошо защищенные в быстро меняющейся России, постоянно нарушаются.

Парадокс ситуации состоит и в том, что в настоящее время законы, предоставляющие привилегии женщинам, хак и сами эти привилегии, лишают российских женщин равных возможностей. Так, государство определяет, что труд женщин не должен использоваться для тех или иных вндов работ. По идее, предоставляемые работающим женщинам привилегии должны облегчать им процесс рождения и воспитания детей, позволяя при этом работать, если они этого хотят, а также должны быть направлены на укрепление их семей. Многие работодатели в России, однако, используют сейчас эти привилегии для того, чтобы убедить женщину уйти с работы.

Очевидно, что практическая ценность законодательного закрепления прав женшин означает лишь возможность пользоваться этими правами. Но только при наличии определенных условий такая возможность может превратиться в действительность. Главное это наличие действенных внутригосударственных механизмов защиты провозглашаемых законодательством прав.

Помимо того, что международные правозащитные механизмы обладают рядом недостатков, международное право предоставляет индивиду прямой доступ в международные органы только после того, как исчерпаны все внутригосударственные средства правовой зашиты. В современных мехгосударственных отношениях имплементация прав человека осуществляется законодательными, административными и иными средствами, имеющимися в распоряжении каждого государства, а международные органы лишь контролируют этот процесс.

Среди разнообразных средств обеспечения прав и свобод человека наиболее распространена судебная защита, которая обладает наибольшей эффективностью. Значение судов подчеркивается в Пакте о грахданских и политических правах, а также в статье 8 Всеобщей декларации прав человека, где провозглашается, что «кахдый человек имеет право на эффективное восстановление в 
правах компетентными национальными судами в случаях нарушения его основных прав, предоставленных ему конституцией или законом». Важную роль в этом процессе призван играть российский Конституционный Суд, который принимает $\mathbf{K}$ рассмотрению жалобы «на нарушение законом конституционных прав и свобод»?.

В этом смысле эффективная защита прав женщин неотделима от реформы судопроизводства, так как в современных условиях чрезмерной загруженности и недостаточного финансирования суды не имеют возможности относиться $\mathrm{K}$ проблемам обеспечения прав женщин с должным вниманием. Необходимо тахже преодолеть негативно́е отношение многих юристов, которые не признают, что дискриминация женщин не ограничивается единичными случаями, а представляет собой проблему, требующую отдельного рассмотрения.

Итак, развитие и совершенствование внутригосударственных средств защиты прав женщин долхно осуществляться в контексте обеспечения прав человека вообще. Внутригосударственные правозащитные механизмы особенно важны, тах как многие вопросы регулирования прав и свобод человека все еще остаются в сфере внутренней компетенции кахдого государства, которое самостоятельно, с учетом взятых на себя мехдународных обязательств, определяет время, последовательность и конкретный способ их выполнения.

Большую работу в области признания и обеспечения прав женшин ведут и неправительственные правозащитные организации. Свидетельством этому является Форум НПО по положению женщин-95, который проходил одновременно с пекинской конференцией. Правозащитные движения опираются на национальные условия, но вследствие универсальности принципов, в соответствни с которыми они строят свою деятельность, эти двихения приобретают мехдународный характер. Часть национальных правозащитных организаций черпают силы и поддержку в международных организациях. Все большую значимость приобретают связи мехду национальными и международными неправительственными организациями. Благодаря совместным усилиям неправительственных организаций оқазывается влияние на международное общественное мнение относительно ситуации с правами человека в конкретной стране или регионе, грахдане того или иного государства получают больше информации о функционировании международных механизмов, опыте других государств в этой области. Значение специализированных НПО, вероятно, будет возрастать, так каK подобные организации имеют возможность сконцентрировать свои усилия на решении исключительно гендерных проблем. Представляется, что неправительственные организации обладают 
большим потенциалом, который может быть реализован как на национальном, так и на мехдународном уровне, в целях обеспечения более эффективной защиты прав женщин.

${ }^{1}$ Аталия Молокомме. Экономические права женщин в контексте прав человека//Заявляем наши права. - М., 1996. - С. 42.

${ }^{2}$ См. Хилкка Пиетила, Дхинии Виххерс. Казалось бы, что могут охндать женшины от такого воплошения патриархата, хаким являотея правительства стран-членов ООН?/Мы, иароды Объеднненньх Нашй... M., 1995. - C. 195.

3 Хроника ООН. - 1995. - Ноя6рь. - № 2.

- Doc. UN.A/Conf.157/DC1/Add. 2. - 1993. - June 25.

5 См. Флоренс Бутегва. Недостатки системы прав человека в сфере зашиты женских прав//Заявляем наши права. - С. 21.

6 B.f. Карташкин. Права человека в международном и внутригосударственном праве. - М., 1995. - С. 63, 83.

' Кристин Чинкин. Контроль за соблюдением человеческих прав женщин в регионах: европейсках система//Заявляем наши права. - С. 88.

- См. Хьюман Райтс Вотч. Проект по правам женщин «Россия: ни работы, ни справедливости (Дискриминация женщин со стороны государства)». -1995.

9 Закон «О Конституционном Суде Российской Федерации». - М., 1994. - Ст. 97.

Cmambr nocmynura o pedaxuuro \& Mapme 1996 a. 